\title{
Optimization of temperature and drying time of indigenous cocktail yeast mold culture using response surface methodology (RSM)
}

\author{
${ }^{1, *}$ Rahmawati, R., ${ }^{2}$ Hunaefi, D., ${ }^{1}$ Basriman, I., ${ }^{3}$ Saputra, D., ${ }^{2}$ Apriliani, A.A. and \\ ${ }^{2}$ Jenie, B.S.L. \\ ${ }^{1}$ Food Technology Program, Sahid University, Jl Prof. Dr. Supomo SH. Nomor 84, Jakarta Selatan 12870, \\ Indonesia \\ ${ }^{2}$ Departement of Food Science and Technology and SEAFAST Center, Bogor Agricultural, University (IPB), \\ Kampus IPB Darmaga PO Box 220 Bogor 16002, Indonesia \\ ${ }^{3}$ Department of Food Technology, Bina Nusantara University, Jl. Jalur Sutera Barat Kavling 21, \\ Tangerang, 15326, Indonesia
}

\begin{abstract}
Article history:
Received: 7 July 2019

Received in revised form: 29

September 2019

Accepted: 30 September 2019 Available Online: 17 October 2019
\end{abstract}

\section{Keywords:}

Cocktail yeast mold,

Dried culture,

Drying temperature and time,

Optimization,

RSM

DOI:

https://doi.org/10.26656/fr.2017.4(2).247

\begin{abstract}
The study was conducted to obtain an optimal combination of time and temperature of the drying process of indigenous cocktail yeast mold culture using RSM. The cocktail yeast mold culture was dried using an oven. The cocktail cultures contain Penicillium citrinum, Aspergillus niger, Acremonium strictum, and Candida famata, namely AC (Amylolytic Culture). The Response Surface Methods (RSM) with Design-Expert ${ }^{\circledR} 7.00$ software, namely Mixture design with D-optimal was performed. The drying time was between 24$48 \mathrm{hrs}$ and the drying temperature was between $40-50^{\circ} \mathrm{C}$. The total of 16 formulas of the combination of drying time and temperature for processing the dried cultures were produced by RSM. The response chosen was total viability of mold and yeast, water content, water activity, and $\mathrm{pH}$. The result of optimization and verification was obtained by the model: $\mathrm{pH}(\mathrm{AC})=-0.058 \mathrm{~A}-1.56 \times 10^{-003} \mathrm{~B}+7.13$, where $\mathrm{A}=$ drying temperature $\left({ }^{\circ} \mathrm{C}\right), \mathrm{B}=$ drying time (hr). The AC optimization was achieved at a combination of drying temperatures and time of $50^{\circ} \mathrm{C}$ for $48 \mathrm{hrs}$. Desirability values were 0.729 . The optimum formula for AC has viability of total yeast mold of $7.39 \times 10^{6} \mathrm{CFU} / \mathrm{g}$, moisture content of $5.62 \%, \mathrm{a}_{\mathrm{w}} 0.303$, and $\mathrm{pH} 4.18$.
\end{abstract}

\section{Introduction}

Fermented corn flour made from local white corn anoman variety has been done. The results of Farasara et al. (2014) showed that the fermentation process changed the characteristics of corn flour produced compared to its natural flour. Likewise, the results of research by Rahmawati, Maulani and Saputra (2018), the use of different types of starter produces different characteristics of flour. The use of indigenous microorganisms in the form of fresh starter cultures is not easy to carry and keep it. To overcome this and facilitate the fermentation process, Rahmawati et al. (2017) made a dried cocktail of starter culture that consists of indigenous yeast and mold. A dried starter culture is easier to carry and keep it. A good starter culture will produce a good product. To produce optimal products, it is needed to optimize the process of making dried culture as well, especially the process of making dried indigenous cocktail starter culture. The cocktail starter culture is made using an oven as a dryer. The temperature and drying time affected the viability of microorganisms. This will affect the quality of the resulting cocktail starter culture. Based on this, the research was conducted to obtain the optimum combination of time and temperature that will produce the best quality of dry indigenous cocktail starter culture. Optimization of the process of making starter culture was carried out by the Response Surface Methodology (RSM) method with Design-Expert ${ }^{\circledR} 7.00$ software, namely Mixture design with D-optimal.

RSM is a statistical and mathematical technique used for the development, improvement, and optimization of production processes by estimating the relationship between independent variables and the results (responses) observed so that obtaining optimum information about independent variables influences the response. This method has long been used in biological research and food technology applications, especially in the stages of the process and formulation optimization (Myers et al. 2009). In making dried cocktail starter 
culture, the viability of microorganisms is very important so that the fermentation process runs optimally. Besides the water content and water activity will affect the long shelf life. Based on this, the response chosen in determining the optimization of dried indigenous cocktail yeast mold culture is the viability of microorganisms (total mold and yeast), moisture content, water activity, and $\mathrm{pH}$.

This study aims to obtain the optimum temperature and drying time in making indigenous cocktail yeast mold culture, namely $\mathrm{AC}$ with the response specified above. The AC cocktail cultures contain Penicillium citrinum, Aspergillus niger, Acremonium strictum, and Candida famata. In addition, this study aims to determine the parameters of the optimum process of drying the indigenous cocktail yeast mold culture using an oven with RSM. The determination of the optimum formula is based on the results of the formula response measurement. The indigenous cocktail yeast mold culture is expected to contain the yeast and mold with the optimum number because it will be used to ferment local white corn grits.

\section{Materials and methods}

\subsection{Microorganisms}

Microorganisms used as a starter culture prepared were $P$. citrinum, A. niger, A. strictum, and C. famata, namely AC. The microorganisms used were previously isolated and identified from spontaneous fermentation of corn grits (Rahmawati et al., 2013).

\subsection{Culture preparation and enumeration}

A loop of each mold was streaked onto fresh Potato Dextrose Agar (PDA) slant and then incubated at $30^{\circ} \mathrm{C}$ for five days. After five days, molds were harvested by scraping, suspended in $10 \mathrm{~mL}$ sterile water and appropriately diluted for enumeration using hemacytometer. Yeast culture was prepared as above, but incubation was carried out at $30^{\circ} \mathrm{C}$ for two days. Yeast enumeration was also carried out using hemacytometer (Farasara et al., 2014).

\subsection{The process of making AC-indigenous cocktail yeast mold culture}

AC-indigenous cocktail yeast mold culture consists of indigenous amylolytic yeast and mold culture from Rahmawati et al. (2013). Growing media used in making cocktail yeast and mold culture is corn flour (Rahmawati et al. 2017). The drying process in making cocktail yeast mold culture is carried out based on the formulation suggested by RSM.
The technique of making cocktail yeast mold culture includes the stages: sterilizing corn flour, then put it into a sterile basin and adding sterile distilled water as much as $2 / 3$ of the total weight of corn flour. Prepared culture suspensions (AC) containing $10^{6} \mathrm{CFU} / \mathrm{mL}$ per microorganism, then piped as much as $10 \%$ of the amount of water used. After that, all stir until homogeneous and put \pm 17 grams in each petri dish. Petri dishes were then incubated at $30^{\circ} \mathrm{C}$ for 5 days. Furthermore, the dough is dried using an oven with a range of $40-50^{\circ} \mathrm{C}$ for $24-48$ hours. The dried ACindigenous cocktail yeast mold culture is made powder using a blender that has been sprayed with $70 \%$ alcohol. The AC-indigenous cocktail yeast mold culture powder is packed in plastic clips with silica gel and then tested for viability (total number of yeast molds), water activity, water content and $\mathrm{pH}$.

2.4 Optimization of the drying process of making $A C$ indigenous cocktail yeast mold culture using the RSM method

Optimization of the drying process of making ACindigenous cocktail yeast mold culture was carried out by the Response Surface Methodology (RSM) method through the Design Expert® 7.00 (DX7) statistical application. The experimental design was made with the aim of obtaining a combination of several components with an optimum response (Myers et al., 2009). The mixture design used is D-optimal. The independent variables in the experiment are drying time (h) and drying temperature $\left({ }^{\circ} \mathrm{C}\right)$. The drying time is between $24-$ $48 \mathrm{hrs}$ and the drying temperature is $40-50^{\circ} \mathrm{C}$ (Rahmawati et al., 2017) (Table 1). After the RSM issued a suggestion on the optimum process for making AC-indigenous cocktail yeast mold culture was made.

Table 1. Independent variables and the level used in the experiments

\begin{tabular}{lcc}
\hline \multirow{2}{*}{ Independent variables } & \multicolumn{2}{c}{ Limits } \\
\cline { 2 - 3 } & Lower $(-1)$ & Upper $(+1)$ \\
\hline Temperatures $\left({ }^{\circ} \mathrm{C}\right)$ & 40 & 50 \\
Times $(\mathrm{h})$ & 24 & 48 \\
\hline
\end{tabular}

\subsection{AC-indigenous cocktail yeast mold culture analysis}

The product produced is tested for the response. The responses observed were viability (CFU/g), moisture content (thermo-gravimetry) (AOAC 2006), water activity (Aw meter Rotronic Hygrolab) (AOAC 2006), and degree of acidity $(\mathrm{pH}$ meter Orion ThermoScientific) (AOAC 2006). Of the four responses, viability is determined to be maximized with a scale of interest of 5 (very important). Where water content, water activity and $\mathrm{pH}$ values are minimized with a scale of interest of 3 (important). This is because the main value expected is the total viability of the molds 
produced optimally so that the yeast will be effective if used during the fermentation process.

\subsection{Statistical analysis}

Data that has been obtained is then processed using Design Expert software. The results obtained will be translated into the model of the response function equation to the independent variable chosen for the response and interaction between responses. In the final stage of optimization, the program will recommend an optimal combination of processes. Optimal conditions are chosen by comparing the value of the desirability of each solution. The selected combination is the one with the highest desirability value.

\section{Results and discussion}

\subsection{Optimization of drying process parameter and} verification of the model

Table 2 shows that the model can describe the relationship of drying process parameters (drying temperature and time) to viability, moisture content, water activity, and $\mathrm{pH}$ value, which are linear and quadratic models. The significance value of the model, lack of fit, and determination coefficient (predicted Rsquared, adjusted R-squared) indicate that there was a match between the distribution of data and the model.
The model also showed precision adequacy values (Adeq. Precision $>4$ ).

\subsection{Yeast mold viability}

The AC indigenous cocktail yeast mold culture had a viability value ranged from $\log 4.2041$ - $\log 8.1139$ $\mathrm{CFU} / \mathrm{g}$. Figure 1 shows that the viability of yeast molds tends to decrease with higher temperatures and longer drying time. Data can be seen in Table 3. This is because the higher the temperature and drying time can cause mold yeast to die. However, in general, the viability of yeast molds in the AC indigenous cocktail yeast mold culture is relatively high. Pitt and Hocking (2009) stated that Penicillium, Rhizopus, Aspergillus grew optimally at temperatures of $35-37^{\circ} \mathrm{C}$. The viability of total yeast mold in the AC dried culture is an important parameter in determining the culture quality because it will act as a starter culture in the white corn grits fermentation process. Rahmawati et al. (2017) found that AC-starter culture has been drying by oven at $40^{\circ} \mathrm{C}$ for $48 \mathrm{hrs}$, has yeast mold availability as $\log 7.66 \mathrm{CFU} / \mathrm{g}$. Besides that, the results are in line with Oliveira et al. (2002) where the minimum number of microorganisms for the starter is $10^{6} \mathrm{CFU} / \mathrm{mL}$. Yuliana and Rizal (2006) stated that the ideal conditions for using a starter culture as an inoculum is equal to $2.1 \times 10^{7} \mathrm{CFU} / \mathrm{g}$. As a comparison, the $\mathrm{CC}$ indigenous cocktail yeast mold culture has a viability

Table 2. The math model of drying proses parameter as a response of the AC indigenous cocktail yeast mold culture

\begin{tabular}{lcccccc}
\hline \multicolumn{1}{c}{ Parameters } & Math model & Significance model & Lack of fit & Adj R $^{2}$ model* & Pred R $^{2}$ model* & Adeq precision* $^{*}$ \\
\hline Viability (CFU $/ \mathrm{g})$ & Quadratic & 0.0272 & 0.0415 & 0.5099 & 0.3083 & 5.041 \\
Water content $(\%)$ & Linear & 0.0031 & 0.0375 & 0.5255 & 0.4423 & 7.68 \\
Water activity $\left(\mathrm{a}_{\mathrm{w}}\right)$ & Linear & 0.0427 & 0.3158 & 0.2897 & 0.1237 & 4.622 \\
Degree of acidity $(\mathrm{pH})$ & Linear & 0.0032 & 0.2709 & 0.5234 & 0.3883 & 6.721 \\
\hline
\end{tabular}

*Information: Adj= Adjusted; Pred= Predicted; Adeq= Adequate

Table 3. The viability, water content, $\mathrm{a}_{\mathrm{w}}$ and $\mathrm{pH}$ responses for AC indigenous cocktail yeast mold culture as the result of RSM optimization

\begin{tabular}{|c|c|c|c|c|c|c|}
\hline \multirow{2}{*}{ Number } & \multicolumn{2}{|c|}{ Independent variables } & \multirow{2}{*}{$\frac{\text { Viability }}{(\text { Log CFU/g)* }}$} & \multirow{2}{*}{ Water content $(\%)^{*}$} & \multirow{2}{*}{$\mathrm{a}_{\mathrm{w}}$ content* } & \multirow{2}{*}{$\mathrm{pH}$ value* } \\
\hline & Drying temperature $\left({ }^{\circ} \mathrm{C}\right)$ & Drying time $(\mathrm{h})$ & & & & \\
\hline 1 & 40 & 24 & $8.11^{\mathrm{abc}}$ & $7.33^{q}$ & $0.464^{\mathrm{k}}$ & $4.57^{\mathrm{fg}}$ \\
\hline 2 & 40 & 24 & $7.30^{\mathrm{abc}}$ & $6.44^{\mathrm{q}}$ & $0.463^{\mathrm{k}}$ & $5.05^{\mathrm{fg}}$ \\
\hline 3 & 40 & 36 & $8.04^{\mathrm{abc}}$ & $7.21^{\mathrm{p}}$ & $0.427^{\mathrm{ijk}}$ & $4.68^{\mathrm{ef}}$ \\
\hline 4 & 40 & 48 & $7.97^{\mathrm{abc}}$ & $7.31^{\mathrm{q}}$ & $0.391^{\text {ghij }}$ & $4.94^{\mathrm{g}}$ \\
\hline 5 & 40 & 48 & $7.61^{\mathrm{abc}}$ & $7.31^{\mathrm{q}}$ & $0.426^{\text {ghij }}$ & $4.96^{\mathrm{g}}$ \\
\hline 6 & 43 & 27 & $6.78^{\mathrm{a}}$ & $5.63^{\mathrm{e}}$ & $0.312^{\text {bcdef }}$ & $4.27^{\mathrm{abc}}$ \\
\hline 7 & 44 & 37 & $6.87^{\mathrm{a}}$ & $6.24^{\mathrm{j}}$ & $0.439^{\mathrm{jk}}$ & $4.19^{\mathrm{ab}}$ \\
\hline 8 & 45 & 48 & $6.58^{\mathrm{a}}$ & $6.93^{\circ}$ & $0.336^{\mathrm{ef}}$ & $4.27^{\mathrm{abc}}$ \\
\hline 9 & 46 & 33 & $5.18^{\mathrm{a}}$ & $5.07^{\mathrm{c}}$ & $0.284^{\text {abcde }}$ & $4.50^{\mathrm{de}}$ \\
\hline 10 & 47 & 24 & $5.50^{\mathrm{ab}}$ & $5.57^{\mathrm{d}}$ & $0.319^{\text {bcdef }}$ & $4.69^{\mathrm{cd}}$ \\
\hline 11 & 47 & 24 & $4.84^{\mathrm{a}}$ & $5.93^{\mathrm{d}}$ & $0.309^{\text {bcdef }}$ & $4.43^{\mathrm{cd}}$ \\
\hline 12 & 48 & 39 & $4.20^{\mathrm{a}}$ & $4.37^{\mathrm{a}}$ & $0.262^{\mathrm{abc}}$ & $4.48^{\mathrm{g}}$ \\
\hline 13 & 50 & 30 & $6.45^{\mathrm{a}}$ & $5.95^{\mathrm{h}}$ & $0.296^{\text {fghi }}$ & $4.22^{\mathrm{abc}}$ \\
\hline 14 & 50 & 30 & $7.28^{\mathrm{a}}$ & $5.78^{\mathrm{h}}$ & $0.451^{\text {fghi }}$ & $4.22^{\mathrm{abc}}$ \\
\hline 15 & 50 & 48 & $7.15^{\mathrm{a}}$ & $5.72^{f}$ & $0.334^{\mathrm{def}}$ & $4.16^{\mathrm{ab}}$ \\
\hline 16 & 50 & 48 & $6.77^{\mathrm{a}}$ & $5.72^{f}$ & $0.298^{\mathrm{def}}$ & $4.12^{\mathrm{ab}}$ \\
\hline
\end{tabular}

*Samples means with same superscripts in the same column are not significantly at $\alpha=0.05$ 
value ranged from $\log 6.23$ to $\log 8.43 \mathrm{CFU} / \mathrm{g}$ (Rahmawati et al., 2018)

The model chosen by the program for the appropriate viability response was quadratic with an $\mathrm{R}^{2}$ value of 0.5099 (Figure 1). The viability response model (AC) has an $F$ value of 4.12 with a p-value (Prob $>F$ ) was 0.0272 whereby the model was significant at $\alpha<$ 0.05 . However, the ANOVA results did not show that the drying temperature and time significantly affected the viability response with a significant lack of fit value which was smaller than $0.05(0.0415)$. The value of lack of fit is bad, the result is significant because it describes the suitability of the model with the response (Keshani et al., 2010).

The AC-indigenous cocktail yeast mold culture consists of more than one microorganism. So, the activity of $\mathrm{AC}$ during the fermentation process varies, because the optimum conditions for growth during incubation for each microorganism vary and maybe there was competition for nutrients by microorganisms varies.

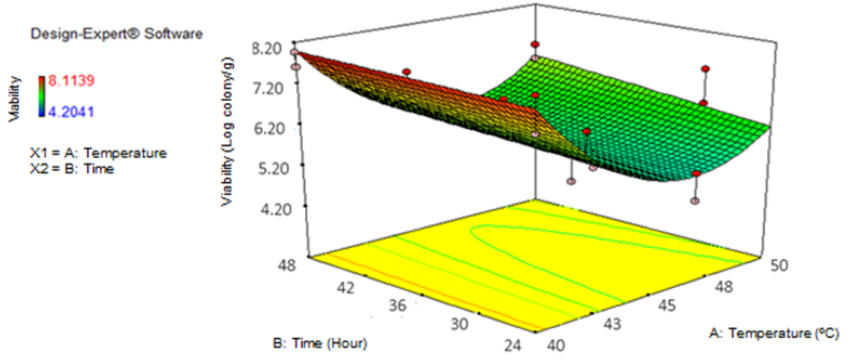

Figure 1. A 3D Graphical combination between temperature and drying time to the viability of AC starter.

\subsection{Water content}

The moisture content of AC-indigenous cocktail yeast mold culture ranges from $4.37-7.33 \%$. Figure 2 shows that the percentage of moisture content tends to decrease with higher temperatures and longer drying time. Rasulu et al. (2012) stated that the water content value is influenced by drying process because the drying process facilitates water evaporation. The moisture content is relatively low because during the fermentation process starch degradation occurs in corn flour accompanied by the formation of simple sugars and release of water. Degradation of starch by microbes caused a decrease in the ability of materials to retain water because of the loss of hydroxyl groups which play a role in absorbing water. Water content determines the shelf life of the product to be stored because it is a marker of the availability of water in food for living microorganisms (Barbosa-Canovas et al., 2007). It means products that have lower water content will have a longer shelf life.
The model chosen by the program for the appropriate moisture content response was linear with an $\mathrm{R}^{2}$ value of 0.5255 (Figure 2). This model response has a F value 9.31 with p-value (Prob $>F$ ) was 0.0031 which is significant at $\alpha=0.05$. However, the ANOVA results did not show that the drying temperature and time significantly affected the water content response with a significant lack of fit value which was smaller than 0.05 (0.0375). A significant lack of fit values illustrates model not suitability with responses.

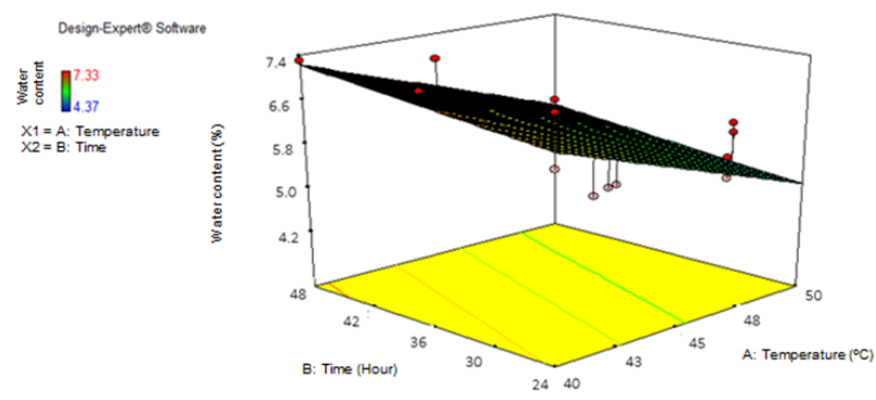

Figure 2. A 3D graphical combination between temperature and drying time to the moisture content of $\mathrm{AC}$ starter

\subsection{Water activity}

The $\mathrm{a}_{\mathrm{w}}$ value for AC-indigenous cocktail yeast mold culture ranges from $0.262-0.464$. Figure 3 shows that the $a_{w}$ value tends to decrease with higher temperatures and longer drying time. This result was in line with Rahmawati et al. (2017) that AC starter culture has $\mathrm{a}_{\mathrm{w}}$ value is 0.450 . Water activity $\left(\mathrm{a}_{\mathrm{w}}\right)$ is a parameter that shows the amount of free water in a product. Free water in food is needed by microbial growth for nutrient processes, media for enzymatic reactions and synthesis of cellular components (Rahayu and Nurwitri, 2012). The product that has a lower $\mathrm{a}_{\mathrm{w}}$ value will have a longer shelf life because microorganisms can only live in certain aw conditions. In general, yeast molds can live at certain minimum aw values. Aspergillus lives at a minimum of aw 0.78 , Penicillium 0.88 , and yeast can generally live at $a_{w}$ around $0.88-0.94$. The minimum water activity for mold growth is 0.80 , while yeast can grow at a minimum of $0.88 \mathrm{a}_{\mathrm{w}}$. The AC-culture has lower $a_{W}$ value. Based on the food stability map as a function of water activity this AC-culture will be degraded by lipid oxidation, non-enzymatic browning, and enzymatic reaction (Barbosa-Canovas et al., 2007).

The model chosen by the program for the corresponding $\mathrm{a}_{\mathrm{w}}$ response is linear (Figure 3). This model showed that the response was affected by drying temperature and time, not by the interaction. The RSM equation or model for optimization of water activity for AC-indigenous cocktail yeast mold culture is as follows:

$$
\mathrm{a}_{\mathrm{W}}(\mathrm{AC})=-0.011 \mathrm{~A}-5.12 \times 10^{-004} \mathrm{~B}+0.87
$$


Where $\mathrm{a}_{\mathrm{W}}=$ water activity; $\mathrm{A}=$ drying temperature $\left({ }^{\circ} \mathrm{C}\right)$; and $\mathrm{B}=$ drying time $(\mathrm{hr})$.

This model has a F value 4.06 with $\mathrm{p}$-value $($ Prob $>\mathrm{F})$ is smaller than $0.05(0.0427)$. It showed that the model was significant at $\alpha=0.05$, which means it can describe that the $\mathrm{a}_{\mathrm{w}}$ response quite well. The ANOVA results also showed that the drying temperature and time had a significant effect on $\mathrm{a}_{\mathrm{w}}$ response with insignificant lack of fit values which were greater than $0.05(0.3158)$. The value of lack of fit is greater than 0.05 , which indicated that it was not significant describing the model mismatch with the response (Keshani et al., 2010). The equation showed that the effect of temperature and drying time is inversely proportional to water activity. That is, the drying temperature and time higher can cause a lower water activity.

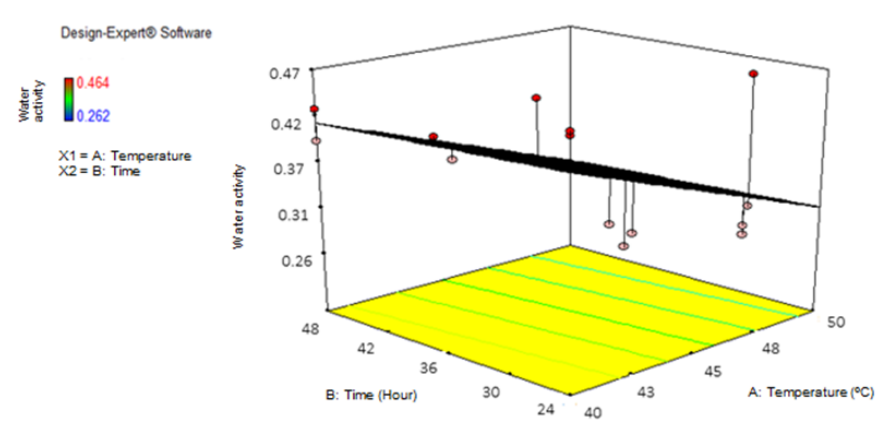

Figure 3. A3D graphical combination between temperature and drying time to the $\mathrm{a}_{\mathrm{w}}$ (water activity) of AC starter

\section{$3.5 \mathrm{pH}$ value}

The $\mathrm{pH}$ value of AC-indigenous cocktail yeast mold culture ranges from 4.12-5.05. Figure 4 shows that the $\mathrm{pH}$ value tends to decrease with a higher temperature and a longer drying time. The $\mathrm{pH}$ value or acidity level shows the active hydrogen ion concentration. The $\mathrm{pH}$ value is used to determine the various types of microbes that may grow in products where each microbe has a specific growth $\mathrm{pH}$. This $\mathrm{pH}$ value is in line with previous studies, namely indigenous yeast mold yeast at pH 4-5 (Rahmawati et al., 2017). The results of the Pratama et al. (2013) showed that the $\mathrm{pH}$ values of starter culture for bread, tempe, and Lactobacillus plantarum are 4.37, 3.43, and 3.93 respectively in $96 \mathrm{hrs}$ fermentation. The $\mathrm{pH}$ value affects the microorganism's growth and life. Each type of microbe has an optimum $\mathrm{pH}$ and $\mathrm{pH}$ range for its growth. In general, mold and yeast can grow in a wider $\mathrm{pH}$ range than bacteria (Rahayu and Nurwitri, 2012). While molds have a very wide $\mathrm{pH}$ growth range, which is between 2.0 to 8.5 , yeast has a $\mathrm{pH}$ range of growth between 4.0 to 4.5 and will not grow well in alkaline environments (Muchtadi and Sugiyono, 2013). During fermentation, a group of microorganisms is capable of fermenting nutrients contained in food to convert some or all of the food components into fermented products, such as lactic acid, ethanol, $\mathrm{CO}_{2}$, or other organic acids. The accumulation of organic acids caused the $\mathrm{pH}$ to decrease during incubation. According to Kartohardjono et al. (2007), that $\mathrm{CO}_{2}$ gas contributes to reducing the $\mathrm{pH}$ value.

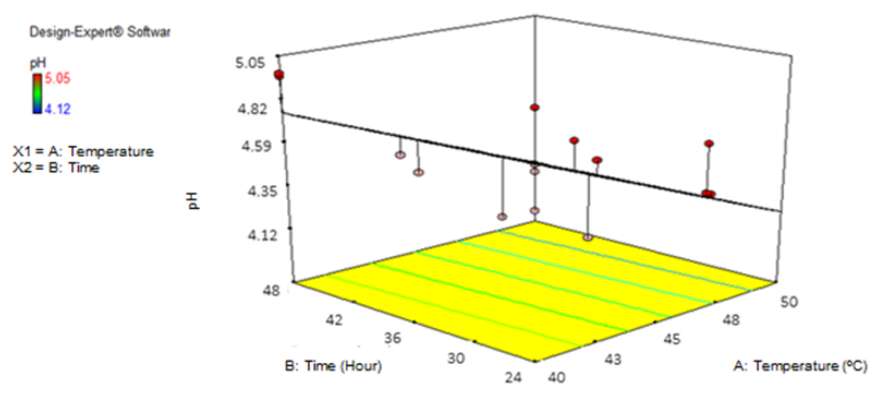

Figure 4. A 3D graphical combination between temperature and drying time to the $\mathrm{pH}$ value of $\mathrm{AC}$ starter

The selected model by the program for the $\mathrm{pH}$ response in the appropriate AC-cocktail culture is a linear model with an $\mathrm{R}_{2}$ value of 0.5869 . This model is significant with a value of $p<0.05$ (Figure 4). The RSM equation or model for optimization of $\mathrm{pH}$ for $\mathrm{AC}$ indigenous cocktail yeast mold culture is as follows:

$$
\mathrm{pH}(\mathrm{AC})=-0.058 \mathrm{~A}-1.56 \times 10^{-003} \mathrm{~B}+7.13444
$$

Where $\mathrm{A}=$ drying temperature $\left({ }^{\circ} \mathrm{C}\right)$; and $\mathrm{B}=$ drying time (hr)

The ANOVA showed that the drying temperature and time had a significant effect on the $\mathrm{pH}$ response of AC-indigenous cocktail yeast mold culture with an insignificant lack of fit values which were greater than 0.05 (0.2709). These results showed that the obtained model has a match with the linear design. The value of lack of fit is good, the result is not significant because it describes the suitability of the model with the response (Keshani et al. 2010).

During the fermentation process yeast activity will produce acids such as lactic acid, acetic acid and ethanol and $\mathrm{CO}_{2}$ which reduce the $\mathrm{pH}$ value (Corsetti and Settanni, 2007). In addition, acid production also affects the aroma of the final product. Yeast is more resistant to acidic conditions than mold. Halm et al. (2004) reported that yeast has a high tolerance for lactic acid. Even Candida crusei found in corn fermentation for ogi production can stimulate the growth of Lactobacillus plantarum. The decrease in the $\mathrm{pH}$ value of $\mathrm{AC}$ yeast is caused by the activity of molds and amylolytic yeasts that hydrolyze amylose into sugar which then becomes organic acid.

Yeast used as a starter culture is also reported to produce various enzymes, for example Kodamae ohmeri produces phytase enzymes in grains (Li et al., 2008) and 
Table 4. The ANOVA test results in the optimum formulation response of drying AC culture

\begin{tabular}{lccccc}
\hline \multicolumn{1}{c}{ Response } & Actual & Prediction & SE mean & 95\% CI low & 95\% CI high \\
\hline Viability (log colony/g) & 6.4771 & 6.8687 & 0.54 & 5.66 & 8.08 \\
Water content (\%) & 6.02 & 5.62 & 0.31 & 4.96 & 6.28 \\
$\mathrm{a}_{\mathrm{w}}$ & 0.343 & 0.303 & 0.031 & 0.24 & 0.37 \\
$\mathrm{pH}$ & 4.17 & 4.18 & 0.11 & 3.95 & 4.41 \\
\hline
\end{tabular}

lipase (Bussamara et al., 2010); Candida famata produces glucoamylase (Mohammed, 2007) and lipase and protease enzymes (Wojtatowicz et al., 2001); whereas Candida krusei has lipolytic, esterase and amylolytic activity which contributes to the final flavor of food products. Yeast which has lipolytic activity acts as a fatty acid precursor and contributes significantly to the flavor of the final product. Amylolytic yeast can cut complex compounds from starch and oligosaccharides into simple sugars that can improve the nutritional quality of the material, because it becomes easier to digest and plays an important role in the aroma, flavor, taste and structure of the final product (Omemu et al., 2007).

Numerical optimization results obtained from a solution of maize flour drying formula with desirability value for AC 0.729. Desirability value is a parameter that showed the best optimization results with a range of values $0-1$. The closer it is to 1 , the solution recommended by the program is able to fulfill the desires according to predetermined criteria (Myers et al., 2009). The results of the ANOVA test for the four responses are presented in Table 4.

Table 4 shows that the actual value obtained from the four responses on the $\mathrm{AC}$ line is still in the range of 95\% confidence intervals (CI). The suitability between predictions and measurement results shows that the model used is verified and quite consistent. The graph of the relationship between the results of verification between the combination of temperature and duration of drying with AC viability is shown in Figure 3, where the graph of the relationship with moisture content is presented in Figure 4. The combination of corn flour drying formula chosen by the program for $\mathrm{AC}$ was $50^{\circ} \mathrm{C}$ for 48 hours.

\section{Conclusion}

AC-indigenous cocktail yeast mold culture is expected to contain indigenous yeast molds with optimum quality characters that will be used to ferment local white corn grits. The viability, water content, $\mathrm{a}_{\mathrm{w}}$, and $\mathrm{pH}$ responses were measured to optimize 16 formulas. The optimization and verification resulted the following model:

$$
\mathrm{pH}(\mathrm{AC})=-0.058 \mathrm{~A}-1.56 \times 10^{-003} \mathrm{~B}+7.13
$$

Where $\mathrm{A}=$ drying temperature $\left({ }^{\circ} \mathrm{C}\right), \mathrm{B}=$ drying time $(\mathrm{h})$. The AC optimization was achieved at a combination of drying temperatures of $50^{\circ} \mathrm{C}$ for $48 \mathrm{hrs}$. Desirability values are 0.729 . The optimum formula for $\mathrm{AC}$ has viability of $7.39 \times 10^{6} \mathrm{CFU} / \mathrm{g}$, moisture content of $5.62 \%$, $\mathrm{a}_{\mathrm{w}}$ 0.303, and $\mathrm{pH} 4.18$.

\section{Acknowledgment}

The authors would like to acknowledge to the Indonesian Ministry of Research and Higher Education Directorate of Research and Community Empowerment for the grant research No. 107/SP2H/LT/DRPM/IV/2018 on behalf Dr. Rahmawati.

\section{References}

AOAC. (2006). Official Methods of Analysis. Washington D.C., USA: Association of Official Analytical Chemist.

Barbosa-Canovas, G.V., Fontana, A.J.Jr., Schmidt, S.J. and Labuza, T.P. (2007). Water Activity in Foods: Fundamentals and Applications. Iowa, USA: IFT Press - Blackwell Publishing. https:// doi.org/10.1002/9780470376454

Bussamara, R., Fuentefria, A.M., de Oliveira, E.S., Broetto, L., Simcikova, M., Valente, P., Schrank, A. and Vainstein, M.H. (2010). Isolation of a LipaseSecreting Yeast for Enzyme Production in a PilotPlant Scale Batch Fermentation. Bioresource Technology, 101(1), 268-275. https:// doi.org/10.1016/j.biortech.2008.10.063

Corsetti, A. and Settanni, L. (2007). Lactobacilli in sourdough fermentation. Review Food Research International, 40(5), 539-558. https:// doi.org/10.1016/j.foodres.2006.11.001

Farasara, R., Hariyadi, P., Fardiaz, D. and DewantiHariyadi, R. (2014). Pasting Properties of White Corn Flours of Anoman 1 and Pulut Harapan Varieties as Affected by Fementation Process. Food and Nutrition Sciences, 5, 2038-2047. https:// doi.org/10.4236/fns.2014.521215

Halm, M., Hornbæk, T., Arneborg, N., Sefa-Dedeh, S. and Jespersen, L. (2004). Lactic acid tolerance determined by measurement of intracellular $\mathrm{pH}$ of single cells of Candida krusei and Saccharomyces cerevisiae isolated from fermented maize dough. International Journal of Food Microbiology, 94(1), 
97-103.

j.ijfoodmicro.2003.12.019

Kartohardjono, S., Anggara, Subihi, and Yuliusman. (2007). Absorbansi $\mathrm{CO}_{2}$ dari Campurannya dengan CH4 atau N2 melalui Kontaktor Membrane Serat Berongga Menggunakan Pelarut Air. Jurnal Teknologi, 11(2), 97-102 [In Bahasa Indonesia]. https://doi.org/10.7454/mst.v11i2.532

Keshani, S., Luqman, C.A., Nourouzi, M.M., Russly, A.R. and Jamilah, B. (2010). Optimization of concentration process on pomelo fruit juice using response surface methodology (RSM). International Food Research Journal, 17(3), 733-742.

Li, X.Y., Liu, Z.Q. and Chi, Z.M. (2008) Production of Phytase by a Marine Yeast Kodamaea ohmeri BG3 in an Oats Medium: Optimization by Response Surface Methodology. Bioresource Technology, 99 (14), 6386-6390. https://doi.org/10.1016/ j.biortech.2007.11.065

Muchtadi, T.R. and Sugiyono. (2013). Prinsip Proses dan Teknologi Pangan. Bandung, Indonesia: Alfabeta. [In Bahasa Indonesia].

Myers, R.H., Montgomery, D.C. and Anderson-Cook, C.M. (2009). Response Surface Methodology: Process and Product Optimization Using Designed Experiments. $3^{\text {rd }}$ ed. New Jersey, USA: John Wiley and Sons, Inc.

Oliveira, M.N., Sodini, I., Remeuf, R., Tissier, J.P. and Corrieu, G. (2002). Manufacture of Fermented Lactic Beverages Containing Probiotic Cultures. Journal of Food Science, 67(6), 2336-2341. https:// doi.org/10.1111/j.1365-2621.2002.tb09550.x

Omemu, A.M., Oyewole, O.B. and Bankole, M.O. (2007) Significance of Yeasts in the Fermentation of Maize for ogi Production. Food Microbiology, 24(6), 571-576. https://doi.org/10.1016/j.fm.2007.01.006

Pitt, J.I. and Hocking, A.D. (2009). Fungi and Food Spoilage. $3^{\text {rd }}$ ed. USA: Springer. https:// doi.org/10.1007/978-0-387-92207-2

Pratama, A.Y., Febriani, R.N. and Gunawan, S. (2013). Pengaruh ragi roti, ragi tape, dan Lactobacillus plantarum terhadap total asam laktat dan $\mathrm{pH}$ pada fermentasi singkong. Jurnal Teknik Pomits, 2(1), 2301-9271. [In Bahsasa Indonesia].

Rahayu, W.P. and Nurwitri, C.C. (2012). Mikrobiologi Pangan. Bogor (ID): IPB Press.

Rahmawati, Dewanti-Hariyadi, R., Hariyadi, P., Fardiaz, D. and Richana, N. (2013). Isolation and Identification of Microorganisms during Spontaneous Fermentation of Maize. Jurnal Teknologi dan Industri Pangan, 24, 38-44. https:// doi.org/10.6066/jtip.2013.24.1.33
Rahmawati, R., Maulani, R.R. and Saputra, D. (2017). Karakteristik Ragi Kapang Khamir Indigenus untuk pembuatan tepung jagung putih lokal fermentasi. Proceeding Seminar Nasional PATPI 2017: Peran ahli teknologi pangan dalam mewujudkan ketahanan pangan nasional. Bandar Lampung, Indonesia. [In Bahasa Indonesia].

Rahmawati, R., Maulani, R.R. and Saputra, D. (2018). Chemical properties, particle shape, and size of fermented local white corn flour of anoman fs variety. Jurnal Teknologi, 80(5), 155-161. [In Bahasa Indonesia]. https://doi.org/10.11113/ jt.v80.11017

Rahmawati, R., Hunaefi, D., Basriman, I. and Saputra, D. (2018). Optimasi Proses Pengeringan Ragi CC dengan Response Surface Methodology (RSM). TECHNOPEX-2018 Institut Teknologi Indonesia, 174-183.

Rasulu, H., Yuwono, S.S. and Kusnadi, J. (2012). Karaktersitik tepung ubi kayu terfermentasi sebagai bahan pembuatan sagukasbi. Jurnal Teknologi Pertanian, 13(1), 1-7. [In Bahasa Indonesia].

Wojtatowicz, M., Chrzanowska, J., Juszczyk, P., Skiba, A. and Gdula, A. (2001). Identification and Biochemical Cha- racteristics of Yeast Microflora of Rokpol Cheese. International Journal of Food Microbiology, 69(1-2), 135-140. https:// doi.org/10.1016/S0168-1605(01)00582-7

Yuliana, N. and Rizal, S. (2006). Optimasi pengolahan durian fermentasi (tempoyak). Laporan Penelitian Hibah Bersaing XIII. Bandar Lampung, Indonesia: Universitas Lampung. [In Bahasa Indonesia]. 